early report summed up the entire connection between the various units as foliows :-

"A battery or rheomotor of unit electromotive force will generate a current of unit strength in a circuit of unit resistance and in the unit of time will convey a unit quantity of electricity through the circuit and do a unit of work or its equivalent."

$\mathrm{Mr}$. Duddell's report on the proceedings at the St Louis Conference brought up the question of electrical standards in its present-day phase. Mr. Duddell referred to two important resolutions passed at St. Louis, and the question of giving effect to these was considered. Since then matters have progressed considerably, and a conference was held at Charlottenburg at which representatives from America, Austria, Belgium, France, Germany, and Great Britain were present, and the following resolution was adopted :-

"In view of the fact that the laws of different countries in relation to electrical units are not in complete agreement, the conference holds it desirable that an official conference should be held in the course of a year with the object of bringing about this agreement."

The result of the above resolution is that a future conference will be held this year in London, when the question of the fundamental electric units will be brought up. Only two electrical units will be chosen as fundamental ones, and these will in all probability be the international ohm, defined by the resistance of a column of mercury, and the international ampere, defined by the deposition of silver.

The international volt will depend on the above two definitions. Experiments have been going on in all countries since October last to determine with extreme accuracy the quantity of silver deposited in a given time and the best method of constructing practical standards having a resistance of one ohm, and these results will be considered at the conference to be held in London this autumn, when we may hope that definitions of the international ohm and ampere will be finally settled.

Not only is it necessary that the fundamental units of electrical science should be the same throughout the world, but the conviction has grown stronger that the extension of this principle would be of enormous assistance to the welfare of nations in general, and consequently international standardisation has become of the greatest importance.

At the St. Louis Congress two years ago Colonel Crompton introduced this question, with the result that it was unanimously agreed that the cooperation of the technical societies should be secured in order that the questions of the standardisation of the nomenclature and ratings of electrical apparatus and machinery might be thoroughly discussed. The Institution of Electrical Engineers appointed an executive committee for this purpose, and practically all the civilised nations of the world cooperated.

In this way the International Electrotechnical Commission was formed, and the central offices are for the present in London, at the offices of the Institution of Electrical Engineers.

The task before the commission is a large one, as the nomenclature alone will probably occupy its attention for a considerable period if one may judge by the labour entailed in the work of the electrical committees of the Engineering Standards Committee, which have been sitting lately.

Standardisation has its dangers as well as its advantages, and it is in the avoidance of the one and the utilisation of the other that the great difficulty attendant on the work of such a commission will consist. It is to be hoped that a happy mean may be found, which, while reducing the number of types of machinery which the responsible consumer or the consulting engineer can order, will not stultify the inventive faculties of engineers towards future developments.

Dr. Glazebrook further gives details of the reports of the Engineering Standards Committee on the various sections of engineering work on which it has already reported, the reading of which is of the greatest interest. The work appears to have been done in a way that is NO. I 954, VOL. 75] thorough and complete, and every endeavour has been made throughout to increase the facilities for obtaining greater output per machine and to reduce the multiplication of patterns.

It is gratifying to know that the work is already bearing fruit, and the recommendations have been adopted by the Government Departments, Lloyd's Registry, the British Corporation, and several other registry societies in regard to ship and boiler specifications. With regard to rails, the Railway Engineers' Association are adopting the standards, and with but few exceptions every new tramway system in this country and many in the colonies which are under construction are being provided with these standard rails. It is estimated that the saving to the British manufacturer by standardisation of iron and steel sections alone will amount to some millions sterling, and we do not think that this figure is exaggerated when we take into consideration the fact that the frequent changing of the rolls to produce in small quantities the many "special" sizes asked for would be done away with.

Although dealing with an infinitesimal part of this vast subject, the address opens out a most important question which will have to be considered, not only by the various branches of the engineering profession, but by every Government that has the welfare of its nation in view. Dr. Giazebrook is to be heartily thanked for the clearness with which he has dealt with his subject, and there is no doubt that his presidential address to the Institution of Electrical Engineers will long be remembered by those who were fortunate enough to hear it.

J. L. M.

\section{THE INFLUENCE OF PARASITES ON THEIR HOSTS.}

SCIENCE of February 8 contains the report of an interesting and suggestive address on this subject delivered by Prof. H. B. Ward before the Section of Biology of the American Association for the Advancement of Science at the New York meeting held in December last. (For other presidential addresses see NATURE of February 7, p. 352.)

After certain preliminary remarks, Prof. Ward mentioned that some parasites, such as the distome Heterophyes, found in the intestine of Egyptian fellahin, seem to have no appreciable effect on their hosts. The African eyeworm (Filaria loa), except when it actually enters the sclerotic of the eye, affords another instance. Many encysted worms likewise come under the same category.

As a rule, single parasites leave no lasting effects on their hosts; it is rather the multiplication of parasites which should be dreaded. The most serious effects occur when this multiplication takes place within the host. On the other hand, when multiplication takes place during successive generations in other hosts, it is unlikely that the parasites, when in the proper stase, will reach the original host in sufficient numbers to cause serious mischief. The real danger lies in a multiple infection through the numerical increase which such a species often undergoes in the intermediate host, or within a limited external area, so that by the intake of a single object a swarm may be introduced.

As a rule, the harm caused by a parasite bears some proportion to its size as compared with that of its host; when, however, parasites occupy positions in connective tissue or between muscular fibres they may be relatively harmless, no matter what their size.

Some parasites cause harm in a mechanical manner, by blocking, for instance, natural passages, or, as in the case of the Egyptian blood-fluke, by the ova entering the capillaries, when serious trouble is bound to ensue. Embryos, in the case of flariæ, may likewise infest the lymphatic vessels, to the great detriment of their host.

The migrations of parasites, as when Ascaris lumbricoides passes along the natural gangways from the intestine to the liver, may also cause serious harm, as abscess of the latter organ. But parasites do not always confine themselves to such natural lines of movement; they may drive 
tunnels for themselves, when still more disastrous results may accrue. The abrasion and destruction of surfaces and cells and the opening up of abnormal communications are not, it is urged, of such serious importance of themselves; it is rather the secondary results from such lesions that are to be feared, such, for example, as the admission of bacteria from the alimentary canal into the blood and tissues. For it is held by many that the normal mucous surface is impenetrable by bacteria, and the germs of cholera and typhoid depend to some extent upon diminished resistance, functional or structural, for their entrance into the tissues.

No one, for instance, doubts that Eberth's bacillus is the active agent of typhoid, but there is strong reason to believe that before it can give rise to the disease there must be lesion of the intestinal mucous membrane. The very fact that out of numbers who drink contaminated water but comparatively few are infected is strong confirmation of this.

Parasites are likewise the inducing cause of changes which lead to multiplication, or proliferation, of cells and tissue, this being the case with both protozoa and bacteria.

The most common morphological change in the host is, perhaps, the development of a cust round the parasite. An example of this is afforded in the case of pearls. In the Ceylon pearl-oyster the production of the best pearls is due to one particular cestode larva which passes part of its existence in the mollusc itself.

On the other hand, the attempt to attribute cancerous and other abnormal growths to the action of parasites does not appear to be supported by the available facts.

As regards such proliferation of tissues as is undoubtedly due to parasitic action, Prof. Ward advances the hypothesis that this may be largely owing to poison generated by the intruder. An inert body, like a grain of sand, will not give rise to the formation of a cyst, or at all events to the proliferation of tissue, and it is probable that pearls cannot be produced by such means. Parasitic bodies, on the other hand, feed and excrete, and nothing is more probable than that the excreta are toxic.

This, however, is not all, for the supply of nutriment to the parasites-nutriment frequently consumed in a wasteful manner-inflicts a severe strain on the host in a large number of instances. The drain on the resources of the latter is, indeed, practically three-fold, owing to the rapid growth of the parasite itself, the production by the latter of a large amount of reserve material (glycogen), and the great reproductive activity of the unbidden guest.

A curious phase of parasitic infection is the frequent loss of reproductive power in the host, due in some instances to destruction of the genital organs themselves, but in others to secondary influences. The tendency for one sex to acquire the sexual characteristics of the other is a marked feature in this parasitic castration.

The destruction of tissue by parasites, as in the case of that of the liver by the liver-fluke, although in one sense a mechanical injury, is really more than this. As the substance removed by the liver-fluke is replaced by connective tissue, a most important organ of the body becomes to a greater or less degree degenerate.

Among the physiological effects of parasitic infection, none is more remarkable than the power possessed by species living upon blood of secreting a substance which prevents the coagulation of that fluid. In regard to what has been stated above as to the development of toxic elements by parasites, the hæemosporidia of malaria undergo development in the red blood-corpuscles, and when they break up into spores the corpuscles are destroyed, with the probable discharge of poison into the blood. As many corpuscles break up at once, the effects are serious. The trypanosomes of sleeping sickness probably have a very similar physiological effect. The existence of a toxic principle affords also the most satisfactory explanation of the phenomena of the progressive, pernicious anæmia present in some cases of bothriocephalid infection. Anæmic conditions are also produced by direct blood-suckers, such as leeches and fish-lice. There remain, however, other forms of anæmia, such as that due to infection by the fishtapeworm Dibothriocephalus latus, the physiology of which cannot at present be satisfactorily explained.

\section{THE BELGIAN INTERNATIONAL BALLOON $S E R V I C E$.}

THE investigation of the higher regions of the atmosphere by means of unmanned balloons, which has been carried on by some countries for several years, generally on the first Thursday in each month, has already revealed some important facts, among which may be mentioned the inversion of temperature at various heights and the determination of the direction of the flow of the upper air-currents over land and sea. The success hitherto attained well repays the expenditure of time and money incurred, and gives good reason for hoping that the study of aggregate results may lead to the ultimate solution of the problem of the general circulation of the atmosphere.

At the instigation of the aëronautical conference held in St. Petersburg in August, 1904, the Belgian Meteorological Service has taken part in this important work since the end of March, 1906, and M. Lancaster has sent us preliminary notes of the results of the monthly ascents from Uccle between April, 1906, and February, 1907, published in Ciel et Terre, and in a note to the Belgian Academy in November, 1906. We have previously referred to the ascents in April and May, but include the data in the following general summary.

The balloons are of india-rubber, coupled in tandem having generally diameters of $1900 \mathrm{~mm}$. and $1350 \mathrm{~mm}$. respectively, and are inflated with hydrogen gas. The meteorograph is made by Bosch, of Strassburg, and consists of barometer (Bourdon tube), two metallic thermometers (Hergesell and Teisserenc de Bort's models), and hair hygrometer. A full description of the apparatus is given in Ciel et Terre for May, I906. In this paper the values quoted are from Dr. Hergesell's thermometer. The starting place of the balloons at Uccle is 100 metres above sea-level, and the ascents were made from about $7 \mathrm{~h}$. to 7h. $3 \mathrm{om}$. a.m. Greenwich time.

General Results of the Ascents.

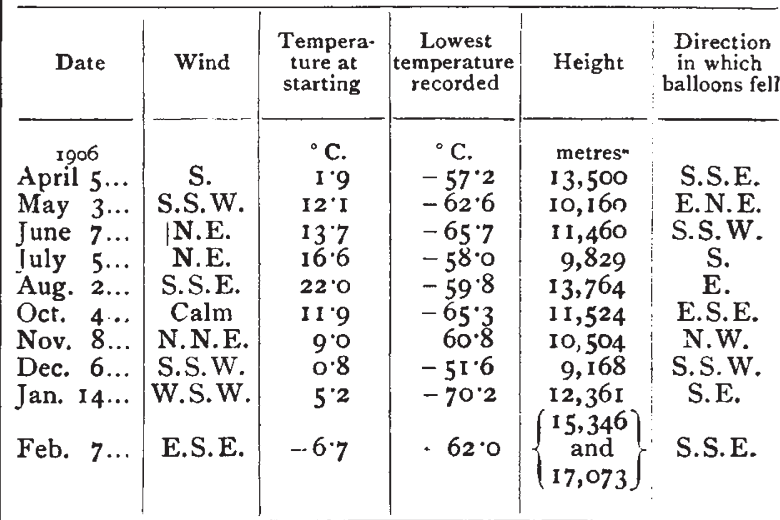

The following details, not included in the above table, are of interest :-

April.--An inversion occurred between 14,000 metres and 15,000 metres.

May.-A large inversion occurred above 10, 160 metres; at the maximum height, 16,970 metres, the temperature had risen to $-42^{\circ} .0 \mathrm{C}$. Humidity fell to 18 per cent. at 10,330 metres, during the descent.

June.-Above II, 460 metres an inversion occurred up to the greatest height, 15,690 metres, where the thermometer read $-54^{\circ} \cdot 5 \mathrm{C}$. Humidity, 22 per cent., at $25^{20}$ metres.

July.-Inversion occurred between 9800 metres and the maximum height, 15,682 metres, where the thermoneter read $-50^{\circ} \cdot 0 \mathrm{C}$; humidity, 19 per cent.

August.-At the maximum height, 18,835 metres, the temperature was $-50^{\circ} \cdot 3 \mathrm{C}$.; between 13,800 metres and 18 , 0oo metres there was an inversion in a layer about 4000 metres in depth.

September.-The meteorograph was broken by collision with buildings at starting. 